Published in final edited form as:

Fitoterapia. 2020 March ; 141: 104479. doi:10.1016/j.fitote.2020.104479.

\title{
Bufadienolides and anti-angiogenic homoisoflavonoids from Rhodocodon cryptopodus, Rhodocodon rotundus and Rhodocodon cyathiformis
}

\author{
Hannah Whitmore ${ }^{\mathrm{a}}$, Kamakshi Sishtla ${ }^{\mathrm{b}}$, Walter Knirsch ${ }^{\mathrm{c}}$, Jacky L. Andriantiana ${ }^{\mathrm{d}}$, Sianne \\ Schwikkard $^{\mathrm{e}}$, Eduard Mas-Claret ${ }^{\mathrm{a}}$, Sarah M. Nassief ${ }^{\mathrm{a}}$, Sani M. Isyakaa ${ }^{\mathrm{a}}$, Timothy W. \\ Corson $^{b,}{ }^{,}$, Dulcie A. Mulholland ${ }^{a, f,{ }^{* *}}$ \\ aNatural Products Research Group, Department of Chemistry, University of Surrey, Guildford GU2 \\ 7XH, United Kingdom \\ ${ }^{b}$ Eugene and Marilyn Glick Eye Institute, Department of Ophthalmology, Indiana University School \\ of Medicine, 1160 W. Michigan St., Indianapolis, IN 46202, USA \\ 'Institute of Plant Sciences, NAWI Graz, Karl-Franzens University Graz, Holteigasse 6, A-8010 \\ Graz, Austria \\ dParc Botanique et Zoologique de Tsimbazaza, Rue Fernand Kassanga, Antananarivo 101, \\ Madagascar \\ eSchool of Life Sciences, Pharmacy and Chemistry, Kingston University, Kingston-upon-Thames \\ KT1 2EE, United Kingdom \\ fSchool of Chemistry and Physics, University of KwaZulu-Natal, Durban, South Africa
}

\section{Abstract}

Background: Homoisoflavonoids have been shown to have potent anti-proliferative activities in endothelial cells over other cell types and have demonstrated a strong antiangiogenic potential in vitro and in vivo in animal models of ocular neovascularization. Three species of Rhodocodon (Scilloideaea subfamily of the Asparagaceae family), endemic to Madagascar, $R$. cryptopodus, $R$. rotundus and $R$. cyathiformis, were investigated.

Purpose: To isolate and test homoisoflavonoids for their antiangiogenic activity against human retinal microvascular endothelial cells (HRECs), as well as specificity against other ocular cell lines.

Methods: Plant material was extracted at room temperature with EtOH. Compounds were isolated using flash column chromatography and were identified using NMR and CD spectroscopy and HRESIMS. Compounds were tested for antiproliferative effects on primary human

\footnotetext{
*Corresponding author. tcorson@iu.edu (T.W. Corson). " Corresponding author at: Natural Products Research Group, Department of Chemistry, Faculty of Engineering and Physical Sciences, University of Surrey, Guildford GU2 7XH, United Kingdom. d.mulholland@surrey.ac.uk (D.A. Mulholland).

Declaration of Competing Interest

There are no conflicts to declare.

Appendix A. Supplementary data

Supplementary data to this article can be found online at http://doi.org/10.1016/j.fitote.2020.104479.
} 
microvascular retinal endothelial cells (HRECs), ARPE19 retinal pigment epithelial cells, 92-1 uveal melanoma cells, and Y79 retinoblastoma cells. HRECs exposed to compounds were also tested for migration and tube formation ability.

Results: Two homoisoflavonoids, 3S-5,7-dihydroxy-( $3^{\prime}$-hydroxy-4' ${ }^{\prime}$-methoxybenzyl)-4chromanone (1) and 3S-5,7-dihydroxy-( $4^{\prime}$-hydroxy-3' ${ }^{\prime}$-methoxybenzyl)-4-chromanone (2), were isolated along with four bufadienolides. Compound $\mathbf{1}$ was found to be non-specifically antiproliferative, with $\mathrm{GI}_{50}$ values ranging from $0.21-0.85 \mu \mathrm{M}$ across the four cell types, while compound 2 showed at least 100-fold specificity for HRECs over the other tested cell lines. Compound 1, with a $3 S$ configuration, was 700 times more potent that the corresponding $3 R$ enantiomer recently isolated from a Massonia species.

Conclusion: Select homoisoflavonoids have promise as antiangiogenic agents that are not generally cytotoxic.

\section{Keywords}

Rhodocodon; Homoisoflavonoids; Bufadienolides; Anti-angiogenic; Neovascularization; Endothelial cells

\section{Introduction}

Abnormal formation of new blood vessels in the eye is associated with blindness in many ocular diseases such as retinopathy of prematurity (ROP) affecting children, proliferative diabetic retinopathy (PDR), the wet form of age-related macular degeneration (AMD) and neovascular glaucoma affecting working-age and older adults, respectively [14]. Small molecule antiangiogenic drugs are urgently needed to supplement the existing available biologies, including drugs such as bevacizumab, ranibizumab, and aflibercept, which target the vascular endothelial growth factor (VEGF) [4]. Homoisoflavonoids, a class of compounds commonly found in the Scilloideae subfamily of the Asparagaceae family, have been shown previously to have potent anti-proliferative activities in endothelial cells over other cell types [17]. Moreover, they demonstrated a strong antiangiogenic potential in vitro and in vivo in animal models of ocular neovascularization [23].

The genus Rhodocodon (Asparagaceae) has been the topic of much taxonomic debate and, in this work, we report on the phytochemical investigation into Rhodocodon cryptopodus $(\mathrm{H}$. Perrier), $R$. rotundus (Baker) and $R$. cyathiformis (var. giganteus). The genus is endemic to Madagascar and thirteen species have been identified based on morphological, biogeographical and molecular evidence [7]. In the 1990s, Speta [20] integrated the genus Rhodocodon into that of Rhadamanthus, effectively replacing the Rhodocodon genus, while Rhadamanthus was subsequently combined with Drimia by Manning et al., giving rise to the synonym Drimia rotunda [10]. Hyacinthus cryptopodus (Baker) (syn. Rhodocodon cryptopodus), which had been placed in the Hyacinthoideae subfamily by Speta [19] as the only Madagascan species in the Hyacinthus genus, was tentatively moved by Manning et al. [10] to the Ledebouria genus, pending further evidence, becoming Ledebouria cryptopoda (Baker) J. C. Manning and Goldblatt. This was due to characteristics unique to the Ledebouria genus such as the fibres produced when the bulb scales are torn. However, in 
2006, this move was re-evaluated by Pfosser et al. [15], who re-assigned L.cryptopodus to the subfamily Urgineoideae, which brought about a necessary transfer from the genus Ledebouria to Drimia as D. cryptopoda (Baker) Pfosser, Wetschnig \& Speta. Rhodocodon Baker has recently been reinstated as a genus within the Scilloideae subfamily of the Asparagaceae (sensu APG III) by Knirsch et al. [7] based on morphological, biogeographical and molecular evidence and Drimia cryptopoda was transferred to this new genus. No medicinal use of any species of Rhodocodon has been reported although the crushed bulbs of $R$. cryptopodus are used for epilation.

The aim of this work was to investigate the phytochemistry of the three Rhodocodon species and to evaluate the homoisoflavonoids isolated for their antiangiogenic activity.

\section{Materials and methods}

\subsection{Instrumentation}

NMR spectra were recorded on a $500 \mathrm{MHz}$ Bruker AVANCE NMR spectrometer in either $\mathrm{CDCl}_{3}$ or $\mathrm{CD}_{3} \mathrm{OD}$, UV-VIS spectra were recorded on a Libra Biochrom spectrometer in $\mathrm{CH}_{3} \mathrm{OH}$ in a $1 \mathrm{~cm}$ cell, IR spectra were obtained using an Agilent (Cary 600 series) FTIR spectrometer (University of Surrey), ESIMS analysis was performed using an Alliance 2695 Quattro Ultra mass spectrometer, HRESIMS data were recorded on an Agilent 6550 iFunnel Q-TOF LC/MS with samples dissolved in $\mathrm{CH}_{3} \mathrm{OH}$. Optical rotations were measured at room temperature in $\mathrm{CH}_{3} \mathrm{OH}$ using a JASCO P-1020 polarimeter and CD spectra were measured on a Chirascan $\mathrm{CD}$ spectrometer using a $1 \mathrm{~mm}$ cell in $\mathrm{CH}_{3} \mathrm{CN}$. Solvents were reagent grade and purchased from Sigma-Aldrich.

\subsection{Plant material}

Plant material of Rhodocodon cryptopodus (Baker), Rhodocodon rotundus (H. Perrier) and $R$. cyathiformis was collected by Dr. Walter Knirsch in Madagascar. Collection permit: 215/13/MEF/SG/DGF/DCB.SAP/SCB, collected 27/12/2016-12/01/2017. Acquisition numbers of the collected plants are $R$. cryptopodus: $02442, R$. rotundus: 04953 and $R$. cyathiformis: WK3. R. cryptopodus was collected from Ambatondradama, Madagascar, and purchased in the market of Antananarivo. R. rotundus was collected from along the roadside on the way to Sakalalina, Madagascar and $R$. cyathiformis was collected near Mahajanga at the Grotte d'Anjohibe. Voucher specimens have been retained at the Karl-FranzensUniversity, Graz, Austria.

\subsection{Extraction and isolation}

The dried bulbs of $R$. cryptopodus $(67.5 \mathrm{~g}$ ) were extracted with EtOH $(550 \mathrm{~mL})$ by shaking at room temperature for $24 \mathrm{~h}$. The EtOH extract (1.806 g) was obtained after solvent evaporation. The extract was separated using gravity column chromatography over silica gel (Merck 9385) to yield $\mathbf{1}$ (5.4 mg), 3 (3.5 mg), 6 (6.2 mg), 7 (2.9 mg), and $\mathbf{1 0}(3.7 \mathrm{mg})$. Dried bulbs of $R$. rotundus $(269.2 \mathrm{~g}$ ) were extracted at room temperature with continuous agitation over $24 \mathrm{~h}$ with EtOH $(200 \mathrm{~mL})$. The resulting EtOH extract $(18.1 \mathrm{~g})$ was separated using a flash column chromatography system to yield compounds $\mathbf{2}(40.0 \mathrm{mg}), \mathbf{4}(7.8 \mathrm{mg}), \mathbf{5}(4.3$ $\mathrm{mg}), \mathbf{8}(40.7 \mathrm{mg})$ and $\mathbf{9}(11.4 \mathrm{mg})$. The fresh bulbs of $R$. cyathiformis $(450 \mathrm{~g})$ were extracted 
with $\mathrm{CH}_{2} \mathrm{Cl}_{2}(1 \mathrm{~L})$ by shaking at room temperature for $42 \mathrm{~h}$. The extract $(2.0 \mathrm{~g})$ was separated using a flash column chromatography system (Biotage SP1 Flash Chromatography Purification System) to yield compounds $\mathbf{1}(1.0 \mathrm{mg})$ and $\mathbf{2}(1.1 \mathrm{mg})$. A detailed separation scheme of each extract can be found in the Supplementary Data, along with spectra.

\subsection{Compound characterization}

Compound 2 yellow oil; $[a]_{\mathrm{D}}^{23}+7.95(c 0.86, \mathrm{MeOH}) ; \mathrm{ECD}\left(\mathrm{CH}_{3} \mathrm{CN}\right) \lambda(\Delta \varepsilon) 230 \mathrm{~nm}$ $(-0.2) 293 \mathrm{~nm}(+2.7), 310 \mathrm{~nm}(-0.1) ;{ }^{1} \mathrm{H} \mathrm{NMR}\left(\mathrm{CDCl}_{3}, 500 \mathrm{MHz}\right)$ and ${ }^{13} \mathrm{C} \mathrm{NMR}\left(\mathrm{CDCl}_{3}\right.$, $125 \mathrm{MHz}$ ) data are given in Table 1. HRESIMS $\mathrm{m} / \mathrm{z} 315.0876[\mathrm{M}-\mathrm{H}]^{-}$(calcd. for $\left[\mathrm{C}_{17} \mathrm{H}_{16} \mathrm{O}_{6}\right.$ - H], $m / z 315.0874)$.

Compound 9 white crystals; $[\mathrm{a}]_{\mathrm{D}}{ }^{23}+40.9(c 0.44, \mathrm{MeOH}) ;{ }^{1} \mathrm{H}$ NMR $\left(\mathrm{CDCl}_{3}, 500 \mathrm{MHz}\right)$ and ${ }^{13} \mathrm{C}$ NMR $\left(\mathrm{CDCl}_{3}, 125 \mathrm{MHz}\right)$ data are given in Table 3. HRESIMS $\mathrm{m} / \mathrm{z} 643.2728[\mathrm{M}+$ $\mathrm{Na}]^{+}$(calcd. for $\left[\mathrm{C}_{32} \mathrm{H}_{44} \mathrm{O}_{12}+\mathrm{Na}\right], \mathrm{m} / z$ 643.2725).

Compound 10 white powder; ${ }^{1} \mathrm{H}$ NMR $\left(\mathrm{CDCl}_{3}, 500 \mathrm{MHz}\right)$ and ${ }^{13} \mathrm{C} \mathrm{NMR}\left(\mathrm{CDCl}_{3}, 125\right.$ $\mathrm{MHz}$ ) data are given in Table 2. ESIMS $\mathrm{m} / \mathrm{z} 190.0631[\mathrm{M}]^{+}$, (calcd. for $\left[\mathrm{C}_{11} \mathrm{H}_{10} \mathrm{O}_{3}\right]^{+}, \mathrm{m} / \mathrm{z}$ 190.0629).

\subsection{Biological assay materials}

Endothelial Growth Medium (EGM-2) was prepared by mixing the contents of an EGM-2 "Bullet Kit" (Cat. no. CC-4176) with Endothelial Basal Medium (EBM) (Lonza). The EGM-2 "Bullet Kit" contains hydrocortisone, human fibroblast growth factor (hFGF), VEGF, R3-insulin like growth factor (R3-IGF-1), ascorbic acid, human epidermal growth factor (hEGF), gentamycin and heparin along with $2 \%$ foetal bovine serum (FBS). Human Retinal Endothelial Cells (HRECs) and Attachment Factor were purchased from Cell Systems (Kirkland, WA, USA). HRECs used for cell proliferation studies were of varying passages (P6-P8) while cells used in tube formation assays were $\mathrm{P} 4$ and migration assays utilised P5. The complete medium used for culturing ARPE-19 cells (ATCC, Manassas, VA, USA) contained Ham's-F10 growth medium (Thermo Scientific, Waltham, MA, USA) + $10 \%$ FBS $+1 \%$ penicillin-streptomycin (pen-strep). 92-1 uveal melanoma cells (a kind gift of Dr. Martine Jager, University of Leiden) were grown in RPMI medium containing 10\% FBS and 1\% pen-strep. Y-79 retinoblastoma cells (a kind gift of Dr. Brenda L. Gallie, Ontario Cancer Institute) were grown in RB medium (IMDM +10\% FBS + $55 \mu \mathrm{M} \beta$ mercaptoethanol $+10 \mu \mathrm{g} / \mathrm{mL}$ insulin $+1 \%$ pen-strep). Matrigel was from Corning (Corning, NY, USA), while alamarBlue was from AbD Serotec (Raleigh, NC, USA).

\subsection{Cell proliferation assays}

Cells $(2,500)$ in growth medium $(100 \mu \mathrm{L})$ were incubated in the centre 48 wells of 96 -well clear bottom black plates overnight, with the surrounding wells containing deionized, sterilised water $(100 \mu \mathrm{L})$. This was followed by treatment of cells with $1 \mu \mathrm{L}$ of different concentrations of each test compound. Compounds were tested in triplicate over the range of $1 \mathrm{mM}$ to $1 \mathrm{nM}(1 \% \mathrm{v} / \mathrm{v}$ final DMSO concentration). Treated cells were incubated for a further $44 \mathrm{~h}$. At the end of this incubation period, alamarBlue reagent $(11.1 \mu \mathrm{L})$ was added and after $4 \mathrm{~h}$ of incubation, fluorescence readings were taken with excitation and emission 
wavelengths of $560 \mathrm{~nm}$ and $590 \mathrm{~nm}$ respectively. Data were analysed and dose response curves generated using GraphPad Prism software (v. 7.0).

\subsection{Migration assays}

The scratch wound migration assay was performed as previously described [2] with HRECs grown in EGM-2 to confluency in a 12 well plate. A scratch was introduced with a sterile 10 $\mu \mathrm{L}$ pipette tip and medium was replaced with EGM- 2 containing the indicated concentrations of compound with $1 \% \mathrm{DMSO} /$ well and wells were imaged by brightfield microscopy to establish scratch width at $t=0$. Cells that migrated into the scratch after $11 \mathrm{~h}$ were manually counted and normalized to control. Statistical analysis using one-way ANOVA with Dunnett's post hoc tests to compare treatment with DMSO control was completed using GraphPad Prism. $P$-values $<.05$ were considered significant.

\subsection{Tube formation assays}

The Matrigel based tube formation assay was performed as previously described [2]. Briefly, $50 \mu \mathrm{L}$ Matrigel was allowed to solidify in a 96 well black, clear bottom plate at $37^{\circ} \mathrm{C}$ for 20 min. HRECs were added to the solid Matrigel at 15,000 cells/well in $100 \mu \mathrm{L}$ EGM-2 and dosed with appropriate concentrations of compound with $1 \mu \mathrm{L}$ DMSO/well. Tube formation was observed every $2 \mathrm{~h}$ by brightfield microscopy and images were taken after $8 \mathrm{~h}$ of tube formation. Six images per treatment were analysed with AngiogenesisAnalyzer plugin for ImageJ (http://image.bio.methods.free.fr/ImageJ/?Angiogenesis-Analyzer-for-ImageJ), and total tubule length for treated cells was normalized to DMSO control. Statistical analysis using one-way ANOVA with Dunnett's post hoc tests to compare treatment with DMSO control data was completed using GraphPad Prism.

\section{Results}

\subsection{Isolation and characterization of compounds from R. cryptopodus}

The EtOH extract of the bulbs of $R$. cryptopodus yielded a $3 S 3$-benzyl homoisoflavonoid, identified as 3S-(5,7-dihydroxy-( $3^{\prime}$-hydroxy-4' ${ }^{\prime}$-methoxybenzyl)-4-chromanone (1), previously reported from Rhodocodon campanulatus but not tested previously for angiogenic activity [16], the cinnamic acid derivative, $p$-hydroxyphenylethyl $p$-coumarate (3), previously reported from Dendrobium falconeri (Orchidaceae), a species of orchid native to Asia, which showed a marginal inhibitory effect $\left(\mathrm{EC}_{50}\right.$ of $\left.352.1 \mu \mathrm{M}\right)$ against Herpes simplex virus type 1 (HSV-1) [21], two known bufadienolide glycosides, deglucohellebrin (6) and hellebrigenin (7), both of which have been isolated from the Helleborous genus (Ranunculaceae) [26] and the previously unreported coumarin (10). Compound $\mathbf{6}$ has been tested previously against oral human squamous carcinoma cells (HSC-2) and human melanoma cells (A 375) and was found to have a potent cytotoxic effect against both $\left(\mathrm{GI}_{50}=2.8 \mathrm{nM}\right.$ and $6.3 \mathrm{nM}$ respectively) [26]. It was also found to have an inotropic effect on cat heart in situ and isolated guinea pig and rat hearts, while compound 7 is known to be cytotoxic against oral human squamous carcinoma cells (HSC-2) $\left(\mathrm{GI}_{50}=2.9\right.$ $\mathrm{nM})$ and human melanoma cells (A 375) $\left(\mathrm{GI}_{50}=8.6 \mathrm{nM}\right)$ [26]. The structures of the compounds were determined using NMR spectroscopy and structures of known compounds were confirmed by comparison against literature values as referenced above. Complete 
NMR assignments for bufadienolides 6-9 (which are not available in the literature) are given (Table 3).

Compound 2, 3S-5,7-dihydroxy-( $4^{\prime}$-hydroxy- $3^{\prime}$-methoxybenzyl)-4-chromanone, gave the same molecular formula $\left(\mathrm{C}_{17} \mathrm{H}_{16} \mathrm{O}_{6}\right)$, ESI-MS peak at $\mathrm{m} / z 315.0876\left([\mathrm{M}-\mathrm{H}]^{-}\right)$and NMR spectrum (Table 1) as a homoisoflavonoid isolated previously from Drimia delagoensis [8]. However, an ECD study showed Cotton effects of +2.8 at $290 \mathrm{~nm}$ and -0.2 at $230 \mathrm{~nm}$ indicating the unusual $3 \mathrm{~S}$ configuration [11]. This agrees with the reported configurations of other 3-benzyl homoisoflavonoids isolated from Rhodocodon which have also been found to have the $3 S$ configuration [16]. Hence compound $\mathbf{2}$ is the $S$-enantiomer of the previously reported $3 R$ isomer.

Compound 9, 6a-acetoxy-3 $\beta, 8 \beta, 14 \beta$-trihydroxy-10,13-dimethylbufa-4,20,22-trienolide 3-

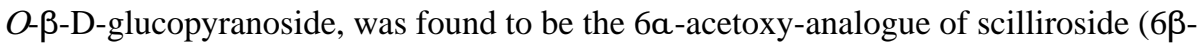
acetoxy-3 $\beta, 8 \beta, 14 \beta$-trihydroxy-10,13-dimethylbufa-4,20,22-trienolide 3- $O$ - $\beta$-Dglucopyranoside), a toxic compound from Urginea maritima, which has been used as a rodenticide [1]. ESI-MS analysis gave a $[\mathrm{M}+\mathrm{Na}]^{+}$peak at $\mathrm{m} / \mathrm{z} 643.2728$, indicating a molecular formula of $\mathrm{C}_{32} \mathrm{H}_{44} \mathrm{O}_{12}$ for the compound. Resonances attributable to carbons and protons of the bufadienolide lactone ring were present (Table 3) and correlations were seen between the $\mathrm{H}-17$ resonance $\left(\delta_{\mathrm{H}} 2.56, \mathrm{dd}, J=9.2,6.5 \mathrm{~Hz}\right)$ and the oxygenated C-14 resonance $\left(\delta_{C} 86.5\right)$ and the $\mathrm{C}-18$ methyl carbon resonance $\left(\delta_{C} 19.8\right)$. The $3 \mathrm{H}-19\left(\delta_{C} 1.36\right)$ resonance showed correlations in the HMBC spectrum with the $\mathrm{C}-10\left(\delta_{\mathrm{C}} 38.1\right), \mathrm{C}-9\left(\delta_{\mathrm{C}}\right.$ 52.2) and alkene $\mathrm{C}-5\left(\delta_{\mathrm{C}} 143.2\right)$ resonances. The $\mathrm{C}-10$ resonance showed correlations with the $\mathrm{H}-4$ alkene $\left(\delta_{\mathrm{H}} 5.94, \mathrm{br}\right.$ s) and $\mathrm{H}-6$ oxymethine resonances $\left(\delta_{\mathrm{H}} 5.47\right.$, dd, $\left.J=8.6,2.6 \mathrm{~Hz}\right)$. Coupling was seen in the COSY spectrum between the H-4 and H-3 $\left(\delta_{\mathrm{H}} 4.26\right.$, bs) resonances. An acetate group was placed at C- 6 due to a correlation seen between an acetate group carbonyl carbon resonance $\left(\delta_{\mathrm{C}} 171.7\right)$ and the H-6 resonance. The orientation of H-6 was established as $\beta$ as correlations were seen in the NOESY spectrum between the H-H-4/ H-6, H-4/3H-19 and H-6/3H-19 resonances. The H-3 resonance showed a correlation with the acetate methyl group proton resonance. The specific rotation of compound 9 was found to be +40.9 , while the literature value for scilliroside has been reported as -59.4 [1].

LRMS of compound $\mathbf{1 0}$ indicated a molecular ion at $\mathrm{m} / \mathrm{z}=190.2$ corresponding to a molecular formula of $\mathrm{C}_{11} \mathrm{H}_{10} \mathrm{O}_{3}$ and seven degrees of unsaturation. The NMR spectra indicated the presence of a substituted coumarin with the $\mathrm{C}-2$ lactone carbonyl resonance occurring at $\delta_{\mathrm{C}} 167.5$ and the $\mathrm{H}-3$ and $\mathrm{H}-4$ resonances appearing as a pair of doublets at $\delta_{\mathrm{H}}$ 5.64 and $\delta_{\mathrm{H}} 7.41$ (both $\mathrm{d}, J=7.8 \mathrm{~Hz}$ ) respectively. The corresponding $\mathrm{C}-4$ resonance $\left(\delta_{\mathrm{C}}\right.$ 143.7) showed a correlation with the $\mathrm{H}-5$ resonance at $\delta_{\mathrm{H}} 6.69(\mathrm{~d}, J=8.0 \mathrm{~Hz})$, which showed coupling in the COSY spectrum with the H-6 $\left(\delta_{\mathrm{H}} 6.54, \mathrm{dd}, J=8.0,2.1 \mathrm{~Hz}\right)$ and $\mathrm{H}-8$ $\left(\delta_{\mathrm{H}} 6.66, \mathrm{~d}, J=2.1 \mathrm{~Hz}\right)$ proton resonances. Both the H-6 and $\mathrm{H}-8$ resonances showed correlations in the $\mathrm{HMBC}$ spectrum with the $\mathrm{C}-9$ methylene carbon resonance $\left(\delta_{\mathrm{C}} 39.9\right)$ and the corresponding $2 \mathrm{H}-9$ triplet $\left(\delta_{\mathrm{H}} 2.68, \mathrm{t}, J=7.4 \mathrm{~Hz}\right.$ ) showed coupling with the $2 \mathrm{H}-10$ oxymethylene proton resonance $\left(\delta_{\mathrm{H}} 3.69, \mathrm{t}, J=7.4 \mathrm{~Hz}\right)$, indicating a hydroxy group at C-10, in accordance with the molecular formula. Although 7-methylated and 7-prenylated coumarins and their derivatives are known, this is the first example of a 7-hydroxyethyl 
coumarin. It could possibly arise from the oxidative degradation of a prenyl group $[3,24,25,28]$. Coumarins have not been reported previously from the Hyacinthaceae [12].

\subsection{Isolation and characterization of compounds from $\mathbf{R}$. rotundus and $\mathbf{R}$. cyathiformis}

The EtOH extract of the bulbs of $R$. rotimdus yielded five compounds, two of which, a rare $3 S$-type 3-benzyl homoisoflavonoid (2) and a bufadienolide glycoside (9), have not been reported previously (Fig. 1). Two known cinnamic acid derivatives, $p$-hydroxyphenethyltrans-ferulate (4), first extracted from Heracleum lanatum [13] and 2-hydroxyethyl-transferulate (ariscucurbin A) (5), previously isolated from Aristolochia cucurbitifolia [27], and $3 \beta, 14 \beta$-dihydroxy-19-oxo-5 $\beta$-bufa-20,22-dienolide 3-O- $\beta$-D-glucopyranoside $(\mathbf{8})$, reported once previously from the related Madagascan Rhodocodon campanulatus [16] were isolated. Compound $\mathbf{4}$ is a known free-radical scavenger [5] which has also been shown to have an affinity toward serotonin $\left(5-\mathrm{HT}_{7}\right)$ receptors [6].

The $\mathrm{CH}_{2} \mathrm{Cl}_{2}$ extract of $R$. cyathiformis yielded compounds $\mathbf{1}$ and $\mathbf{2}$, also isolated in this work from $R$. cryptopodus and $R$. rotundus respectively.

\subsection{Antiproliferative effects of homoisoflavonoids}

Homoisoflavonoids are known to inhibit angiogenesis with some selectivity for blocking the proliferation of endothelial cells over other ocular cell types [2,9]. Thus, they have appeal as a basis for new treatments for neovascular eye diseases such as wet age-related macular degeneration [22]. Because of this, compounds 1 and $\mathbf{2}$ were tested for their antiproliferative activities against human retinal endothelial cells (HRECs), giving excellent $\mathrm{GI}_{50}$ results of $0.13 \mu \mathrm{M}$ and $0.49 \mu \mathrm{M}$ respectively in this assay (Fig. 2). In comparison, the $R$-enantiomer of compound 1, recently isolated from Massonia bifolia and tested for antiproliferative activity against HRECs gave a $\mathrm{GI}_{50}$ of $93.2 \mu \mathrm{M}(\mathrm{R}),>700$-fold less potent than $S$-enantiomer 1 [18].

Although compounds $\mathbf{1}$ and $\mathbf{2}$ are very similar in structure and gave similar $\mathrm{GI}_{50}$ results against the endothelial cells, HRECs, the compounds showed very different activities against other cell lines. Compounds were tested for their specificity against human retinal pigmented epithelial cells (ARPE-19) as well as retinoblastoma (Y-79) and uveal melanoma (92-1) cell lines (Fig. 2). Compound 1 was found to be nonspecific, with $\mathrm{GI}_{50}$ values ranging from $0.21-0.85 \mu \mathrm{M}$ across the four cell types, while compound 2 showed at least 100-fold specificity for HRECs over the other tested cell lines (Fig. 2).

\subsection{Antiangiogenic effects of homoisoflavonoids}

Both compounds 1 and $\mathbf{2}$ were tested for inhibition of key in vitro angiogenic properties of HRECs, migration and tubule formation, and showed dose-dependent blockade of both these properties (Figs. 3 and 4).

\section{Discussion}

The limitations of existing therapies for neovascular eye diseases like wet age-related macular degeneration provide a compelling need for novel pharmacological approaches. 
There is a growing body of evidence showing that homoisoflavonoids have antiangiogenic activity relevant to these diseases, in some cases with limited effects on nontarget cells. Thus, in this study we sought novel homoisoflavonoids from a plant genus known to produce this class of compounds, and tested isolated compounds for antiangiogenic activity.

Despite the similarity in structure of compounds $\mathbf{1}$ and $\mathbf{2}$, compound $\mathbf{1}$ was non-specific for antiproliferative effects on endothelial cells, while compound $\mathbf{2}$ was selective for HRECs. However, both compounds blocked migration and tubule formation of HRECs; these assays provide a good in vitro model of antiangiogenic activity. Taken together, these results suggest that compound $\mathbf{2}$ shows promise for the development of future small molecule treatments for ocular neovascularization, due to its specificity and its excellent activity against HRECs.

\section{Supplementary Material}

Refer to Web version on PubMed Central for supplementary material.

\section{Acknowledgements}

H. Whitmore acknowledges a PhD scholarship from the University of Surrey. Sianne Schwikkard acknowledges support from the Daphne Jackson Trust, the University of Surrey and the Royal Society of Chemistry for funding. T. W. Corson acknowledges support from NIH/NEI R01EY025641, the BrightFocus Foundation, and an unrestricted grant from Research to Prevent Blindness, Inc.

\section{Abbreviations:}

AMD

CD

$\operatorname{COSY}$

EBM

EGM

FBS

FTIR

HMBC

HRECs

HRESIMS

LC-MS

NMR

NOESY

PDR age-related macular degeneration

circular dichroism

correlation spectroscopy

endothelial basal medium

endothelial growth medium

foetal bovine serum

Fourier-transform infrared

heteronuclear multiple bond spectroscopy

human retinal microvascular endothelial cells

high- resolution electrospray ionization mass spectrometry

liquid chromatography-mass spectrometry

nuclear magnetic resonance

Nuclear Overhauser effect spectroscopy

proliferative diabetic retinopathy 

ROP
retinopathy of prematurity
TOF
time of flight
VEGF
vascular endothelial growth factor

\section{References}

[1]. Bahri L, Djegham M, Makhlouf M, Urginea maritima a poisonous plant of North Africa, Vet. Hum. Toxicol 42 (2000) 108-110. [PubMed: 10750179]

[2]. Basavarajappa H, Lee B, Lee H, Sulaiman H, An H, Magaña C, Shadmand M, Vayl A, Rajashekhar G, Kim E, Suh Y, Lee K, Seo S, Corson T, Synthesis and biological evaluation of novel homoisoflavonoids for retinal neovascularization, J. Med. Chem 58 (2015) 5015-5057. [PubMed: 26035340]

[3]. El-Sharkawy ER, Mahmoud K, Cytotoxity of two new coumarin derivatives isolated from Launaea mucronata, Nat. Prod. Res 30 (2016) 394-398. [PubMed: 25751124]

[4]. Folk JC, Stone EM, Ranibizumab therapy for Neovascular age-related macular degeneration, N. Engl. J. Med 363 (2010) 1648-1655. [PubMed: 20961248]

[5]. Hirano H, Tokuhira T, Yokoi T, Shingu T, Isolation of free radical scavenger from Coptidis rhizoma, J. Nat. Med 51 (1997) 539-540.

[6]. Kaewamatawong R, Ruangrungsi N, Likhitwitayawuid K, Chemical constituents of Polyalthia parviflora stem, J. Nat. Med 61 (2007) 349-350.

[7]. Knirsch W, Martínez-Azorín M, Pfosser M, Wetschnig W, The reinstatement and rediagnosis of the Madagascan genus Rhodocodon (Asparagaceae, Scilloideae), with validation and remarks on H. Perrier's taxa, Phytotaxa 195 (2015) 101-134.

[8]. Koorbanally C, Mulholland D, Crouch N, A novel homoisoflavonoid from Drimia delagoensis (Urgineoideae: Hyacinthaceae), Biochem. Syst. Ecol 33 (2005) 743-748.

[9]. Lee B, Basavarajappa H, Sulaiman R, Fei X, Seo S, Corson T, The first synthesis of the antiangiogenic homoisoflavone, cremastranone, Org. Biomol. Chem 12 (2014) 7673-7677. [PubMed: 25167470]

[10]. Manning JC, Goldblatt P, Fay M, Revised generic synopsis of Hyacinthaceae in sub-Saharan Africa, based on molecular evidence, including new combinations and the new tribe Pseudoprospereae, Edinb. J. Bot 60 (2003) 533-568.

[11]. Moodley N, Crouch N, Mulholland D, Slade D, Ferreira D, 3-Benzyl-4-chromanones (homoisoflavanones) from bulbs of the ethnomedicinal geophyte Ledebouria revoluta (Hyacinthaceae), S. Afr. J. Bot 72 (2006) 517-520.

[12]. Mulholland DA, Schwikkard SL, Crouch NR, The chemistry and biological activity of the Hyacinthaceae, Nat. Prod. Rep 30 (2013) 1165-1210. [PubMed: 23892453]

[13]. Nakata H, Sashida Y, Shimomura H, A new phenolic compound from Heracleum lanatum MICHX. var. nippinicum HARA. II, Chem. Pharm. Bull 30 (1982) 4554-4556.

[14]. Penn JS, Madan A, Caldwell RB, Bartoli M, Caldwell RW, Hartnett ME, Vascular endothelial growth factor in eye disease, Prog. Retin. Eye Res 27 (2008) 331-371. [PubMed: 18653375]

[15]. Pfosser M, Wetschnig W, Speta F, Drimia cryptopoda, a new combination in Hyacinthaceae from Madagascar, Linz. Biol. Beitr 38 (2006) 1731-1739.

[16]. Schwikkard S, Alqahtani A, Knirsch W, Wetschnig W, Jaksevicius A, Opara E, Langat M, Andriantiana J, Mulholland D, Phytochemical investigations of three Rhodocodon (Hyacinthaceae Sensu APG II) species, J. Nat. Prod 80 (2017) 30-37. [PubMed: 28051316]

[17]. Schwikkard S, Whitmore H, Sishtla K, Sulaiman RS, Shetty T, Basavarajappa HD, Waller C, Alqahtani A, Frankemoelle L, Chapman A, Crouch N, Wetschnig W, Knirsch W, Andriantiana J, Mas-Claret E, Langat MK, Mulholland D, Corson TW, The Antiangiogenic activity of naturally occurring and synthetic Homoisoflavonoids from the Hyacinthaceae (sensu APGII), J. Nat. Prod 82 (2019) 1227-1239. [PubMed: 30951308] 
[18]. Schwikkard SL, Whitmore H, Corson TW, Sishtla K, Langat MK, Carew M, Mulholland DA, Antiangiogenic activity and cytotoxicity of Triterpenoids and Homoisoflavonoids from Massonia pustulata and Massonia bifolia, Planta Med. 84 (2018).

[19]. Speta F, Kubitzki K (Ed.), The Families and Genera of Vascular Plants III Flowering Plants, Monocotyledons: Lilianae (Except Orchidaceae), Springer, Berlin, 1998, pp. 261-285.

[20]. Speta F, Systematische analyse der Gattung Scilla L. s. 1. (Hyacinthaceae), Phyton 38 (1998) 1141.

[21]. Sritularak B, Likhitwitayawuid K, New Bisbibenzyls from Dendrobium. falconeri, Helv. Chim. Acta 92 (2009) 740-744.

[22]. Sulaiman R, Basavarajappa H, Corson T, Natural product inhibitors of ocular angiogenesis, Exp. Eye Res 129 (2014) 161-171. [PubMed: 25304218]

[23]. Sulaiman RS, Merrigan S, Quigley J, Qi X, Lee B, Boulton ME, Kennedy B, Seo SY, Corson TW, A novel small molecule ameliorates ocular neovascularisation and synergises with antiVEGF therapy, Sci. Rep 6 (2016) 25509. [PubMed: 27148944]

[24]. Tantray MA, Bhat BA, Khuroo MA, Shawl AS, Two new coumarins from Euonymus hamiltonianus, Chem. Nat. Compd 44 (2008) 10-12.

[25]. Tesso H, König WA, Kubeczka K-H, Bartnik M, Glowniak K, Secondary metabolites of Peucedanum tauricum fruits, Phytochemistry 66 (2005) 707-713. [PubMed: 15771895]

[26]. Watanabe K, Mimaki Y, Sakagami H, Sashida Y, Bufadienolide and spirostanol glycosides from the rhizomes of Helleborus orientalis, J. Nat. Prod 66 (2003) 236-241. [PubMed: 12608856]

[27]. Wu T, Leu Y, Chan Y, Constituents of the fresh leaves of Aristolochia cucurbitifolia, Chem. Pharm. Bull 47 (1999) 571-573.

[28]. Yang X-L, Awakawa T, Wakimoto T, Abe I, Induced production of novel prenyldepside and coumarins in endophytic fungi Pestalotiopsis acaciae, Tetrahedron Lett. 54 (2013) 5814-5817. 


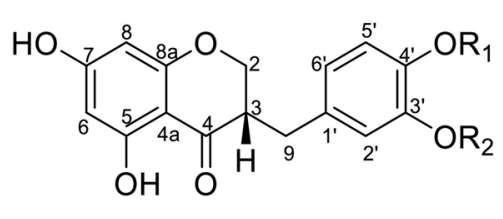

$1 \mathrm{R}_{1}=\mathrm{CH}_{3} \mathrm{R}_{2}=\mathrm{H}$ $2 \mathrm{R}_{1}=\mathrm{HR}_{2}=\mathrm{CH}_{3}$

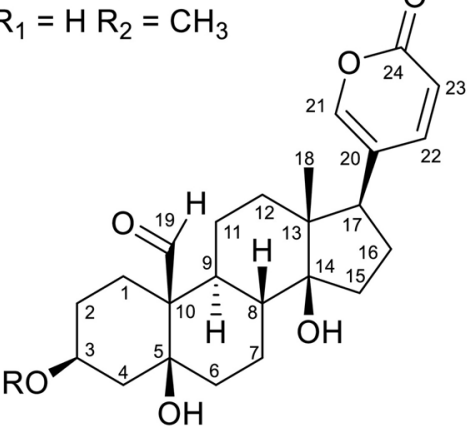

$6 \mathrm{R}=\alpha$-L-rhamnopyranoside $7 \mathrm{R}=\beta$-D-glucopyranoside

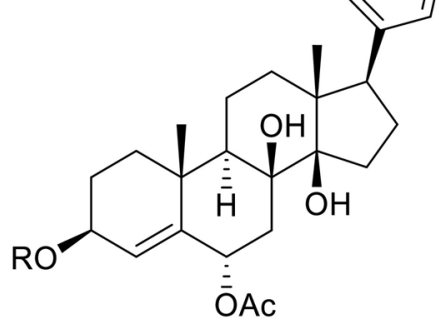

$9 \mathrm{R}=\beta$-D-glucopyranoside<smiles>[R]C=COC(=O)/C=C/c1ccc(O)c([R])c1</smiles>

$3 \mathrm{R}_{1}=\mathrm{H} \mathrm{R}_{2}=p-\mathrm{Ph}-\mathrm{OH}$

$4 \mathrm{R}_{1}=\mathrm{OCH}_{3} \mathrm{R}_{2}=p-\mathrm{Ph}-\mathrm{OH}$

$5 \mathrm{R}_{1}=\mathrm{OCH}_{3} \mathrm{R}_{2}=\mathrm{OH}$

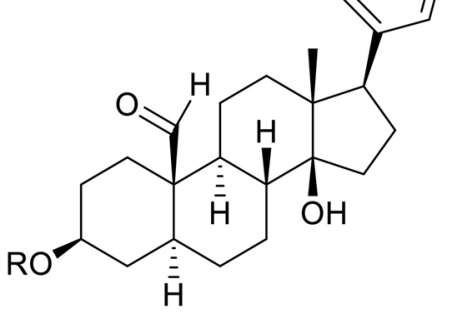

$8 \mathrm{R}=\beta$-D-glucopyranoside

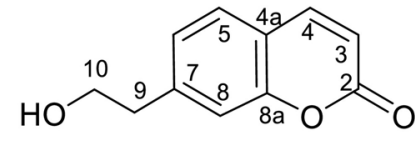

10

Fig. 1.

Compounds isolated from $R$. cryptopodus, $R$. rotundus and $R$. cyathiformis. 

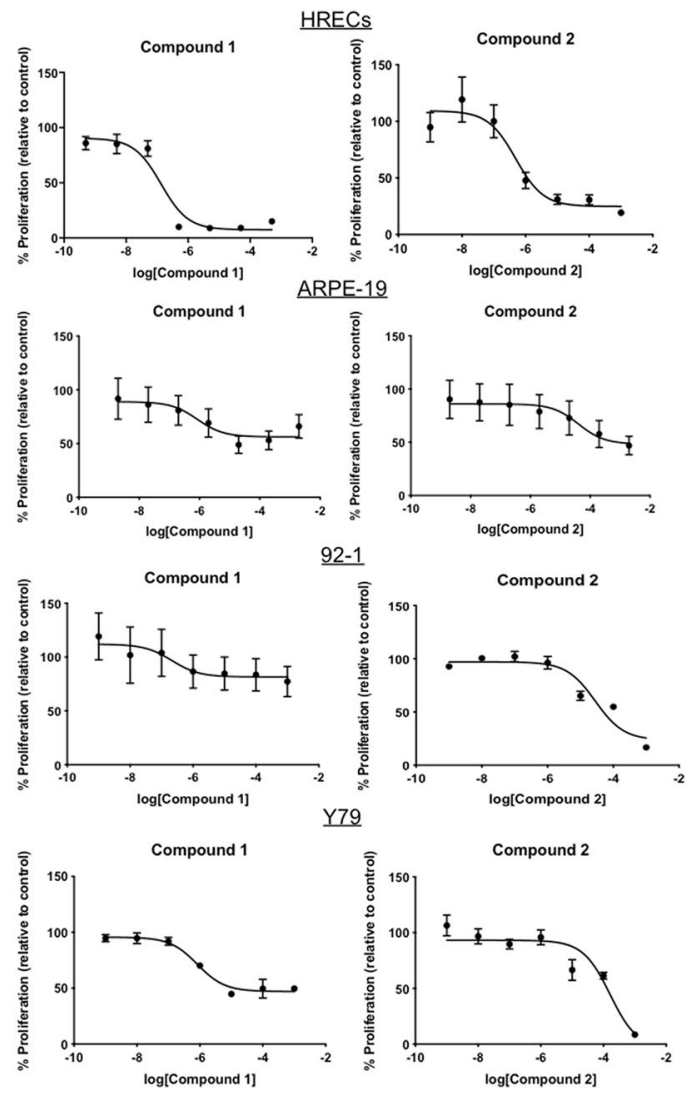

Fig. 2.

Dose-response curves for inhibition of proliferation of indicated cell types by compounds $\mathbf{1}$ and 2. Mean \pm SEM, $n=3$. 

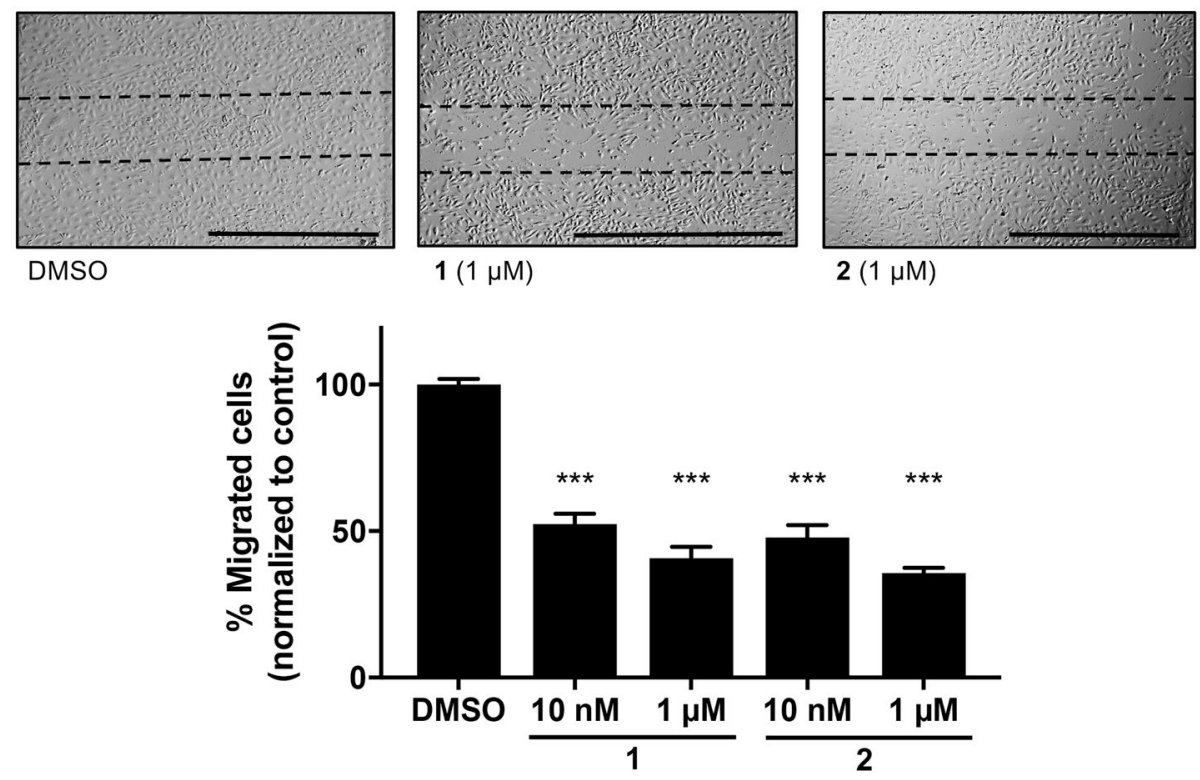

Fig. 3.

Migration assays for HRECs treated with compounds $\mathbf{1}$ and 2. Representative images of the highest concentration treatment of each compound or DMSO control shown (scale bars = 1 $\mathrm{mm}$ ) and quantification of migrated cells. Mean $\pm \mathrm{SEM}, \mathrm{n}=3$. ***, $P<.001$ compared to DMSO, ANOVA with Dunnett's post hoc tests. 


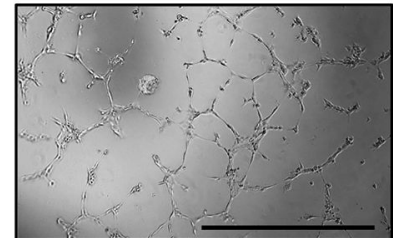

DMSO

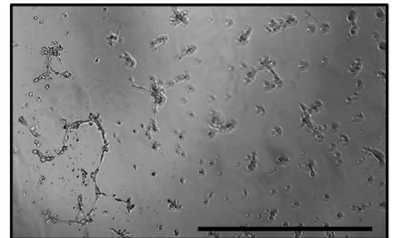

$1(1 \mu \mathrm{M})$

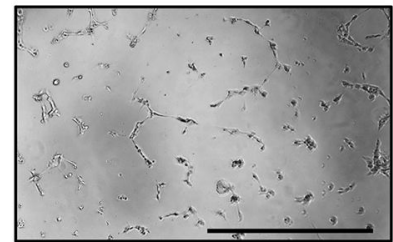

$2(1 \mu \mathrm{M})$

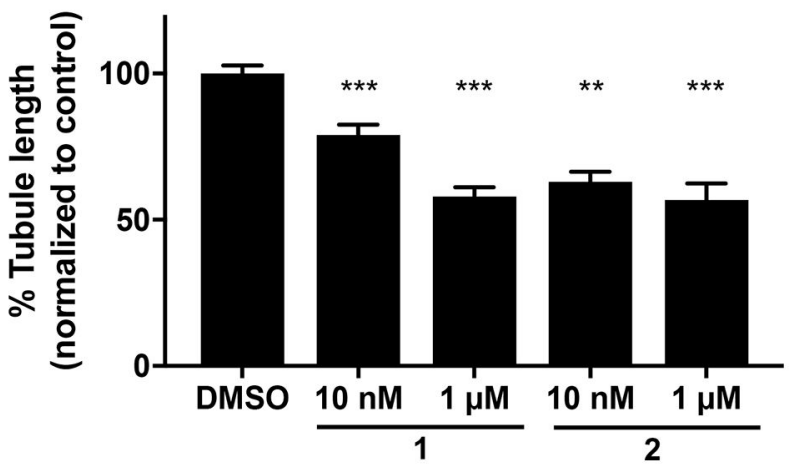

Fig. 4.

Tube formation assays for HRECs treated with compounds $\mathbf{1}$ and $\mathbf{2}$. Representative images of highest concentration treatment of each compound or DMSO control shown (scale bars = $1 \mathrm{~mm}$ ) along with quantification of tubule length, Mean \pm SEM, $n=6$. **, $P<.01 ; * * *, P$ $<.001$, ANOVA with Dunnett's post hoc tests. 
Table 1

NMR data for compounds 1 and $2\left(500 \mathrm{MHz}, \mathrm{CDCl}_{3}, \mathrm{Jin} \mathrm{Hz}\right)$.

\begin{tabular}{|c|c|c|c|c|}
\hline \multirow[t]{2}{*}{ No. } & \multicolumn{2}{|l|}{1} & \multicolumn{2}{|l|}{2} \\
\hline & $\delta_{\mathrm{C}}$ & $\delta_{H}$ & $\delta_{\mathrm{C}}$ & $\delta_{H}$ \\
\hline 2 & 69.3 & $\begin{array}{l}\text { (a) } 4.11(\mathrm{dd}, 11.4,7.4) \\
\text { (ß) } 4.27(\mathrm{dd}, 11.4,4.3)\end{array}$ & 69.1 & $\begin{array}{l}\text { (a) } 4.10(\mathrm{dd}, 11.5,7.0) \\
\text { ( } \beta) .26(\mathrm{dd}, 11.5,4.2)\end{array}$ \\
\hline 3 & 46.9 & $2.83(\mathrm{~m})$ & 46.8 & $2.80(\mathrm{~m})$ \\
\hline 4 & 198.1 & - & 198.3 & - \\
\hline $4 a$ & 103.0 & - & 102.6 & - \\
\hline 5 & 164.9 & - & 165.3 & - \\
\hline 6 & 96.8 & $5.98(\mathrm{~d}, 2.2)$ & 96.9 & $6.01(\mathrm{~d}, 2.5)$ \\
\hline 7 & 164.4 & - & 164.7 & - \\
\hline 8 & 95.2 & $5.91(\mathrm{~d}, 2.2)$ & 95.4 & $5.93(\mathrm{~d}, 2.5)$ \\
\hline $8 \mathrm{a}$ & 163.5 & - & 163.4 & - \\
\hline 9 & 32.4 & $\begin{array}{l}\text { (a) } 3.16(\mathrm{dd}, 14.0,4.6) \\
\text { (b) } 2.65(\mathrm{dd}, 14.0,10.6)\end{array}$ & 32.4 & $\begin{array}{l}\text { (a) } 3.14(\mathrm{dd}, 13.9,4.5) \\
\text { (b) } 2.65(\mathrm{dd}, 13.9,7.0)\end{array}$ \\
\hline $1^{\prime}$ & 131.1 & - & 131.2 & - \\
\hline $2^{\prime}$ & 115.4 & $6.81(\mathrm{~d}, 1.9)$ & 115.4 & $6.80(\mathrm{~d}, 2.3)$ \\
\hline $3^{\prime}$ & 146.0 & - & 145.8 & - \\
\hline 4 & 145.7 & - & 145.7 & - \\
\hline $5^{\prime}$ & 111.0 & $6.80(\mathrm{~d}, 8.1)$ & 111.1 & $6.79(\mathrm{~d}, 8.2)$ \\
\hline $6^{\prime}$ & 120.8 & $6.70(\mathrm{dd}, 8.1,1.9)$ & 120.9 & $6.70(\mathrm{dd}, 8.2,2.3)$ \\
\hline $3^{\prime}-\mathrm{OMe}$ & - & - & 56.2 & $3.88(\mathrm{~s})$ \\
\hline $4^{\prime}-\mathrm{OMe}$ & 56.2 & $3.88(\mathrm{~s})$ & - & - \\
\hline $5-\mathrm{OH}$ & - & $12.13(\mathrm{~s})$ & - & $12.15(\mathrm{~s})$ \\
\hline
\end{tabular}


Table 2

NMR data for compound $10\left(500 \mathrm{MHz}, \mathrm{CDCl}_{3}, J \mathrm{in} \mathrm{Hz}\right)$.

\begin{tabular}{lllllll}
\hline $\mathbf{1 0}$ & & & & & \\
No. & ${ }^{13} \mathbf{C}$ & Type & ${ }^{1} \mathbf{H}(\boldsymbol{J}$ in $\mathbf{H z})$ & $\mathbf{H M B C}(\mathbf{H} \rightarrow \mathbf{C})$ & $\mathbf{C O S Y}$ & NOESY \\
\hline 2 & 167.5 & $\mathrm{C}$ & & & & \\
3 & 101.9 & $\mathrm{CH}$ & $5.64(\mathrm{~d}, 7.8)$ & 4 & 4 & 4 \\
4 & 143.7 & $\mathrm{CH}$ & $7.41(\mathrm{~d}, 7.8)$ & $2,3,4 \mathrm{a}$ & 3 & 3 \\
$4 \mathrm{a}$ & 144.8 & $\mathrm{C}$ & & & & \\
5 & 116.4 & $\mathrm{CH}$ & $6.69(\mathrm{~d}, 8.0)$ & $4,4 \mathrm{a}, 6,7$ & 6 & 6 \\
6 & 121.3 & $\mathrm{CH}$ & $6.54(\mathrm{dd}, 8.02 .1)$ & $4 \mathrm{a}, 5,8$ & 5 & 5,9 \\
7 & 131.9 & $\mathrm{C}$ & & & & \\
8 & 117.3 & $\mathrm{CH}$ & $6.66(\mathrm{~d}, 2.1)$ & $4 \mathrm{a}, 6$ & & 6,9 \\
$8 \mathrm{a}$ & 151.7 & $\mathrm{C}$ & & & & \\
9 & 39.9 & $\mathrm{CH}_{2}$ & $2.68(\mathrm{t}, 7.4)$ & $6,7,8,10$ & 10 & $6,8,10$ \\
10 & 64.8 & $\mathrm{CH}_{2}$ & $3.69(\mathrm{t}, 7.4)$ & 7,9 & 9 & 9 \\
\hline
\end{tabular}




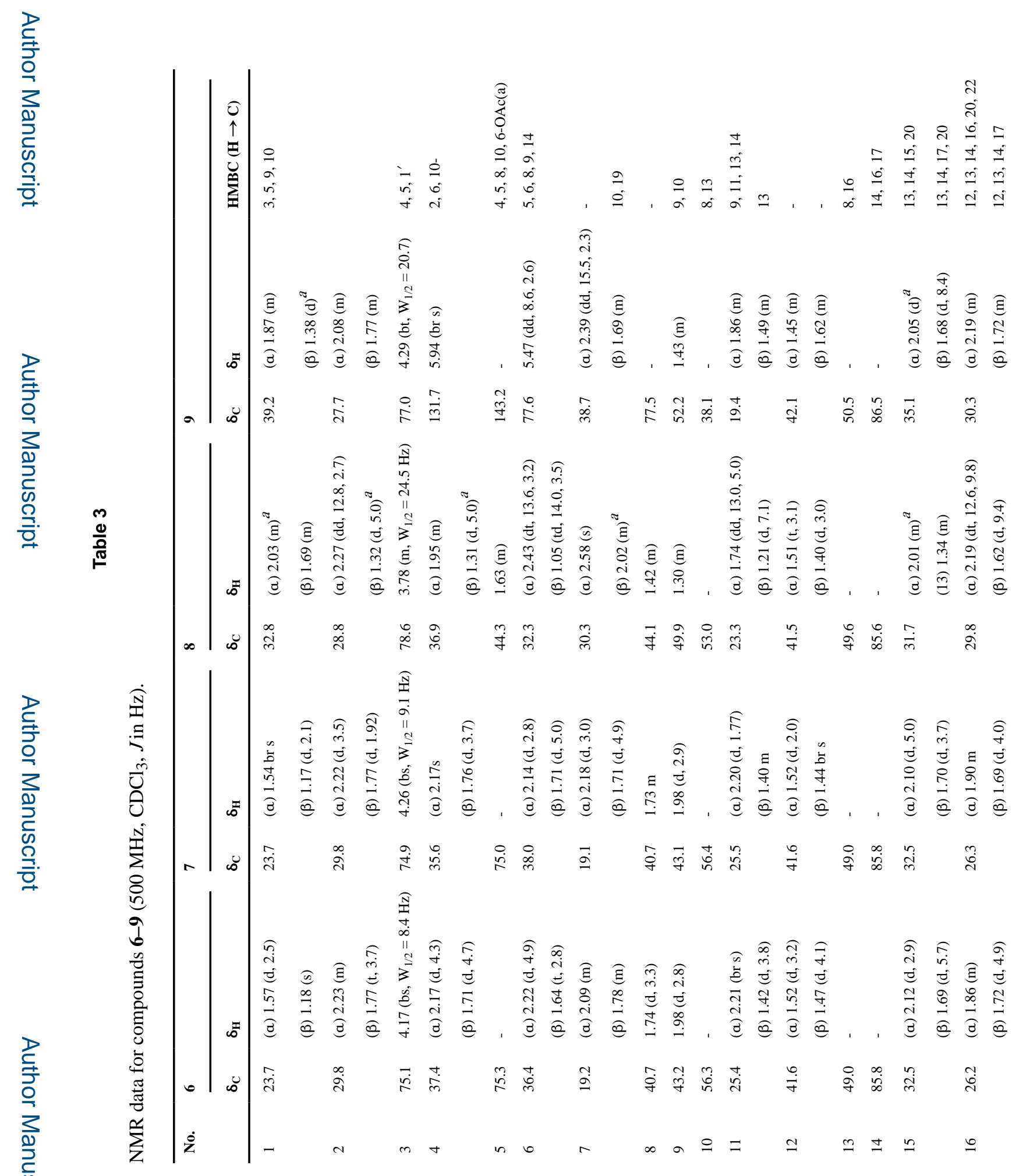

Fitoterapia. Author manuscript; available in PMC 2020 March 11. 


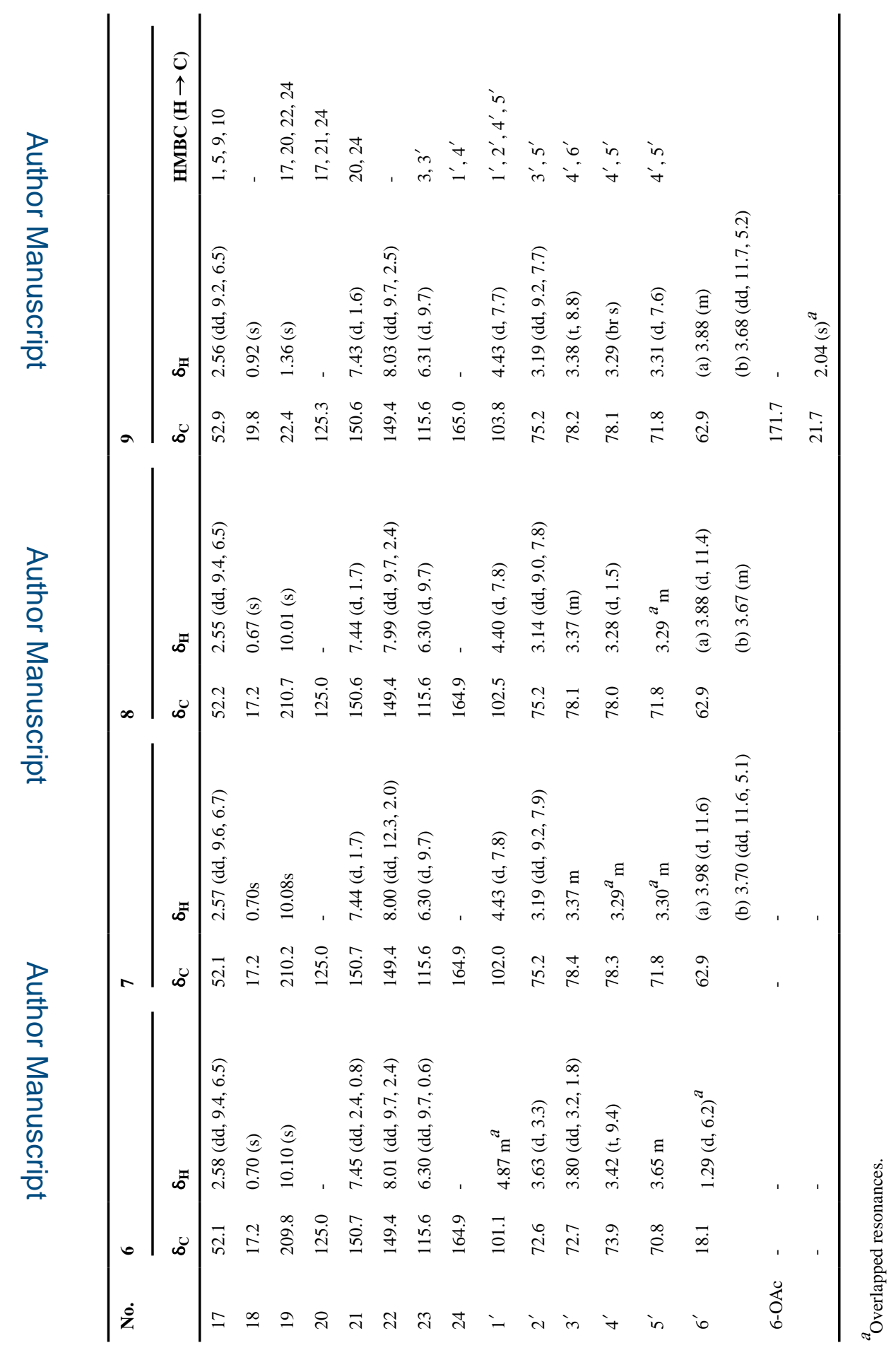

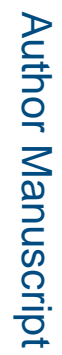

